\begin{tabular}{l} 
International Journal of Applied Business and Economic Research \\
$\begin{array}{l}\text { Applied Business and } \\
\text { Economic Research }\end{array}$ \\
ISSN : 0972-7302 \\
available at http: www.serialsjournal.com \\
C Serials Publications Pvt. Ltd. \\
\hline
\end{tabular}

\title{
Assessing the Climate Change Impact on Farmers Household Welfare According to West Sumatra Agro-Ecological Zone
}

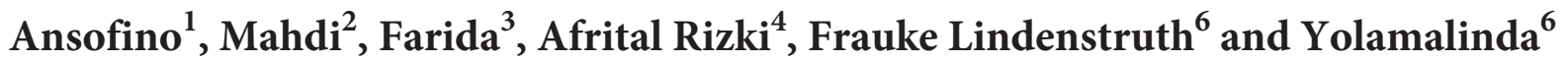 \\ ${ }^{1,6}$ Department of Economic Education, STKIP PGRI WestSumatra, Indonesia.Email: ${ }^{1}$ ansofino2001@yahoo.com and ${ }^{6}$ olamalinda@gmail.com \\ ${ }^{2}$ Agriculture Faculty of Andalas University,West Sumatra, Indonesia Email.kuteibmabdi@yahoo.com \\ ${ }^{3-4}$ Department of Geography Education STKIP PGRI West Sumatra, Indonesia.Email ${ }^{3}$ aifarida@yahoo.com and Afrital.reaki@gmail.com \\ ${ }^{5}$ Geography Department of Christian Alberch-Kiel University, Kiel, Germany.Email frauke_lindenstruth@web.de
}

\begin{abstract}
This study exams impact of climate change on farmer's income and welfare in various agro-ecological zones in West Sumatra, Indonesia. The first assessment is to determine and generate maps of agro-ecological zone of West Sumatra province. The study also assess on farmer's income and welfare as impacts of climate change based on the agro-ecological zone in the region using the concept of length growing period (LGP) in GIS and Ricardian model. We find there are twelve agroecology zones (AEZ) West Sumatra based on soil potensial classification and elevation. Climate change has more big impact on farmer's welfare on soil potensial one zone than soil potential two. The impact of climate change is likely to lead to a decrease in the level of income of household rubber farmers. The impact of climate change are faster and more pronounced in soil potential one compared to soil potential two.
\end{abstract}

Keywords: Climate Change impact, farmer income, Agroecology zone.

\section{INTRODUCTION}

Based on recent IPCC (Intergovernmental Panel on Climate Change) research that the increasing of Green House Gasses (GHG) induced the global warming (IPCC, 2007). If the increase in greenhouse gases and global warming does not attempt to be reduced, it is expected to affect the pressure on the increase in the cost of agricultural products, especially those in areas that are very sensitive to climate change(Seo, Mendelsohn, Dinar, Hassan, \& Kurukulasuriya, 2008). Currently, We need a design for efficient mitigation program in the reduction of greenhouse gas emissions (Bierbaum \& Zoellick, 2009) dan (Nordhaus, 2007). 
One important advantage of the mitigation program is to improve food security, especially on the lives of people in rural areas (Mc Carthy et. al., 2001) and (Ramírez, Kronick, \& Mason, 2012).

The challenge of adapting to climate change is greatest in developing countries for three reason (Millner \& Dietz, 2014) dan (Kurukulasuriya \& Mendelsohn, 2008), (Choumert, Motel, \& Millock, 2015). The first is geography; increase in temperature impact to availiability of water. The second is often called sensitivity; a reltive large share of developing countries output emanates from sectors especially sensitive to climate condition, notably agriculture. The third reason is a lack of adaptive capacity, especially lack the resources to adapt to climate change, including financial resource, good governance, infrastructure and information see (Millner \& Dietz, 2014: 1-33) and (Mendelsohn, Dinar, \& Williams, 2006).

Previous research has identified that the impact of climate change on agriculture in rural areas of developing countries will vary from one zone to another depend upon a number of factors. In designing an appropriate policy which required a reliable indicators of how the impact of climate change on population diversity lanscape agricultural areas. This study using agro-ecological zoning to predict how climate change impacts in West Sumatra as a major area of national food production. Specifically, this study examines how climate change is affecting the of farmer's household welfare in different Agro-ecological Zones (AEZ) in West Sumatra.

Agriculture in different agro-ecological zones farming business practices are different. Each farmer households have particular types of agriculture, irrigation systems, plant species and animal species that are suitable to be developed in accordance with its agroecological zone (Seo et. al., 2008:3-5). If the farmers grow the type of main crop commodities as a source of household income in the suitable ecological zone then the household income will increase in line with higher production. Ricardian analysis tried to advance reduced form regression results on net revenue on climate change, soil, economic and institutional variables. The coefficient of the estimation of reduced form models are then used to measure the climate sensitivity of agriculture and used to predict the impact of climate change in the future, based on the scenario of climate change are made.

Adaptation is implicit and endogeous variable in the Ricardian analysis techniques. It assumes that each farmer's household will maximize their income with the constraints of external conditions, including climate. It is assumed that farmers will choose mix agricultural of paddy fields and plantations as a source of household income. The selection of any input to maximize the income from agricultural activities.

The net of household revenue is determined by the output prices, climate variables, the amount of irrigation water availability, soil characteristics, input prices, rental labor, capital leases and the annual cost of this type of irrigation system. In practice, the net revenue consists of revenues from agricultural plantations, paddy rice farming and livestock businesses. This distinction is important because on the previous studies it only analyze the revenue for one type of agricultural crops.

This study used primary and secondary data. Secondary data was collected from the sources of the registration climatic data such as rainfall, number of rainy days, the rate of infiltration, evapotranspiration rate, altitude, and the type of soil and other climate data. While the primary data such as major commodities, production and average production and revenue of farming households from the cultivation of agriculture. The selection of the sample has been based on the representation of the diversity of AEZ in the region of West Sumatra. 
The research was conducted on the area of West Sumatra province by analyzing the AEZ based on the climate data, soil type and plants growing suitable in particular AEZ. Therefore, the research questions are (1) How many of AEZ in West Sumatra that is suitable to the climatic condition, altitude, soil fertility and types of crops that cultivated by farmers?, (2) What is the impact of climate change on each of the AEZ on the farmers walfare?, (3) How mitigation and adaptation strategies to climate change specially for farmer's community who $t$ are vulnerable to the disaster due to climate change?.

The purposes of this study are: (1) To analyzed and develop AEZ of West Sumatra province based on soil, fertility and crop type, (2) To analyzed the impacts of climate change on AEZ of West Sumatra province, (3) To analyze the revenue of household from major commodities based on AEZ of West Sumatra and (4) To analyze the impact of climate change on revenue of household based on AEZ of West Sumatra.

\section{DESCRIP'TION OF MODEL}

This research is primarily to identify and delineate the AEZ of West Sumatra according to the type of crops grown by the community as their source of household income. Based on the results of the sensitivity analysis, climatic variables which affect AEZ is the most sensitive to changes in climate variables. Information from this study will be useful for policy maker in addressing climate change, which in turn will affect the level of household welfare. The benefits for farming households to determine the types of plants that are appropriate to the existing AEZ.

Agricultural systems developed by farmer is very different among the highland and lowlands region. According to Mendelson (Seo et. al., 2008:5) farming systems in different agro-ecological zones is done in a different way as well depend on the agro-ecological condition. Each farm household will choose particular types of agriculture with particular plant species which are appropriate and suitable to local agro-ecological conditions.

Research on the relationship between agro-ecological conditions with the suitability of crops grown by farmers and its relation to household income as the impact of climate change has been initiated by David Ricardo (1772-1823) so-called "Ricardian analysis" (Seo et. al., 2008:3). Ricardian method is an empirical data collection approach (cross section) to study agricultural production. The initial observations on the value of the land reflected in net productivity. The net revenue of farmland $(\mathrm{V})$ would be reflected in the value of productivity. The principle is calculated by following equation :

$$
\mathrm{V}=\sum \mathrm{P}_{i} \mathrm{Q}_{i}\left((\mathrm{X}, \mathrm{F}, \mathrm{H}, \mathrm{Z}, \mathrm{G})-\sum \mathrm{P}_{x} \mathrm{X}\right)
$$

Where $\mathrm{P}_{i}$ is the market price of the crops, $\mathrm{Q}_{\mathrm{i}}$ is the output of the crops, $\mathrm{X}$ is vector of buying input, $\mathrm{F}$ is vector of climate variables, $\mathrm{H}$ is the flow and water availability, $\mathrm{Z}$ is soil fertility, $\mathrm{G}$ is vector of econimic variable such as access to the market, $\mathrm{P}_{x}$ is price of input.

It assumed that the farmer's household will select the variable of input prices to maximize the revenues with the characteristics of agricultural land and the market price considered as fixed (given) variable. Ricardian model is derived model which examine multiple exogenous variables affect the revenue of farmer's households such as climate variable (rainfall, humidity, evaporation and soil water availability), the availability of surface water, humidity and soil fertility and access to market. Those variables will affect the results of net revenue of farmer's household. 
The standard of Ricardian model (Kurukulasuriya \& Mendelsohn, 2006) based on the quadratic formula from climate change which takes the form of the following functions:

$$
\mathrm{V}=\mathrm{B}_{0}+\mathrm{B}_{i} \mathrm{~F}+\mathrm{B}_{2} \mathrm{~F}^{2}+\mathrm{B}_{3} \mathrm{H}+\mathrm{B}_{4} \mathrm{Z}+\mathrm{B}_{5} \mathrm{G}+\mu
$$

Where: $\mu$ is a form of error variable error. Linear and quadratic form for climate variables such as temperature and the precipitation rate has been specified. It can be use to formulated the expected marginal impact of climate variables using the following formula:

$$
\mathrm{E}\left[d \mathrm{~V} / d f_{i}\right]=b_{1 i}+2 \times b_{2 i} \times \mathrm{E}\left[f_{i}\right]
$$

The quadratic reflecting the non-linear form of household net as the response of climate change function. When the shape of the square has a positive value, then the revenue function will be in the shape of $\mathrm{U}$. When the quadratic form is shaped negative, then the revenue of household function will be ascending. This study expect that based on initial cross section analysis then the value of household agriculture will have hill slope (increase) relation with temperature. Changes in annual welfare as $\Delta \mu$, resulting from climate change mainly of $\mathrm{C}_{0}$ to $\mathrm{C}_{1}$ that can be measured from the following equation:

$$
\Delta \mu=\mathrm{V}\left(\mathrm{C}_{1}\right)-\mathrm{V}\left(\mathrm{C}_{0}\right)
$$

If climate change will increase net revenue of farming household that it will be profitable, otherwise if climate change will lower the acceptance of farmers, then it will be disasterous. Cross-section of data collection between different climates can produce different climate sensitivity among developed agricultural systems in highland and lowland areas of West Sumatra. The advantages of the empirical approach of this Ricardian model of this method not only the direct impact of climate on agricultural productivity, but also adaptive response by farmers in the local climate. The farners behavior is important because it would reduce the problems associated with environmental conditions are less than optimal.

Previous studies have used the approach Ricardian to analyze the impact of climate change on farmers' welfare is often done with a variety of variables modifications specified in building a model of farmers welfare influenced by variable climate and soil fertility.

Among the previous study referenced by Seo et. al., (2008) that it has tested the impact of climate change on the distribution of 16 agro-ecological zones in Africa. This study used data from FAO combined with survey data from the World Bank project on global environment facility. The net revenue of the farmer's household per hectare of agricultural land in Africa regressed with a number of climate variables such as soil fertility, rainfall, precipitation rate and economic variables such as accessibility, using different econometric specification with or without the "country fixed effect". Using a variety of scenarios such as country fixed effect and "mild climate scenario" the Africa farmer households earned income from climate change, and with "more severe scenario" farming households in Africa lose their income in some locations with very big influence of climate change. Analysis of AEZ implies that the impact of climate change will vary among AEZ in Africa, for example, the area of agricultural production in area of dry/humid savannah which is more vulnerable to climate change. So that AEZ classification may help explain the diversity of effects of climate change between landscape in the African region.

Another studies that use Ricardian analysis of the impact of climate change on livelihoods of farmers in rural areas are Seo et. al., (2008) and Kurukulasuriya dan Mendelson (2008). These studies examined the impact of climate change on agricultural crops in Africa, using Ricardian cross section. The research data 
from 11 countries in the agricultural farm of 9500 households. The household annual revenue regressed with climate changes variables and other economic variables. The results of the study suggested that the impact of climate change on net income household varies on AEZ in Africa. Applying of its findings on possible changes on future climate change concluded that dry farming area is very sensitive to climate change until the year 2020. The net revenue will increase by $51 \%$, if the global warming in the future reduced at the level of wet. The contrary to this condition that the revenue will decrease by $43 \%$ if the climate in the future become hotter. In this research, the net revenue of irrigated crop households will have less impact cause by climate change.

Research of (Niggol Seo \& Mendelsohn, 2008) entitled: A Ricardian Analysis of the Impact of Climate Change on South American Agriculture has estimated the impact of climate change on agriculture in South America by entering variable adaptability of farmers in the face of climate change. This study used a Ricardian analysis approach with 2300 farmers to investigate the impact of global warming on value of the land. This study uses three scenarios such as Atmosphere Oceanic General Circulation Model (AOGCM), Canadian Climate Centre (CCC), the Centre for Climate Systems Research (CCSR), and the Parallel Climate scenario model (PCM). Some specifications have been tested and five econometric regression equation has been simulated. For all agricultural systems, small household, commercial farmers, farmer who depend on the season, and irrigated farmer will have decresing of land value will decrease as temperature increases. Using CCC scenario CCC the South American farmers will loss average of 14\% of its income in 2020, and 20\% in the year 2060. Small farming households only lose revenue under the scenario (PCM). Small and large farmers are very vulnerable to climate change.

This study also use Ricardian analysis to analyzed the impact of climate change on farmer's households who undertake agricultural commodity as a source of their revenue. The impact of climate change is to create a scenario based on agro-ecological zones. The results of the preliminary study by Ansofino (2010a), Ansofino (2009) and Ansofino (2011) has identified the major commodities in the province of West Sumatra on agri-food sub-sector, horticulture and plantation crops. The results of this study will be used to select the type of plants that will be used as basis for selecting sample farmer households who cultivate agricultural commodity in different ecological zones. Then using Ricardian analysis to develop a model which consider of climate, soil fertility and economic variables for farmer's welfare acroos West Sumatra province. The estimation results of the variable impact of climate change on farming households revenue, then used to construct the scenario for startegies of mitigation and adaptation farmer in the face of climate change impact in agriculture sector.

\section{RESULT AND DISCUSSION}

AEZ has used the framework for the characteristics of the climate, soil and topography on agricultural production, especially rice paddy fields in West Sumatra. The concept of Length Growing Period (LGP) and climate variability due to altitude/latitudinal thermal climate (Fischer, et. al., (2002) of farmland have been applied for the planning of agricultural activity. The study for Solok and Tanah Datar district has given six zones based on LGP and the altitute for paddy field.

The first step is to develop AEZ West Sumatra is collecting data on land use and the data area of land planted by rice paddy. The LGP calculated using perciptation and evapotranspiration rate precipitasi on paddy fields based on it's latitute. The LGP is reflected the temperature and humidity at various heights 
rice field's altitute. In addition, also use the data for soil potential for paddy field. Then it all combine with Junghun climate classification for various crop based on the altitute (see (Ansofino, Mahdi, Ai Farida, Rezki, 2016)
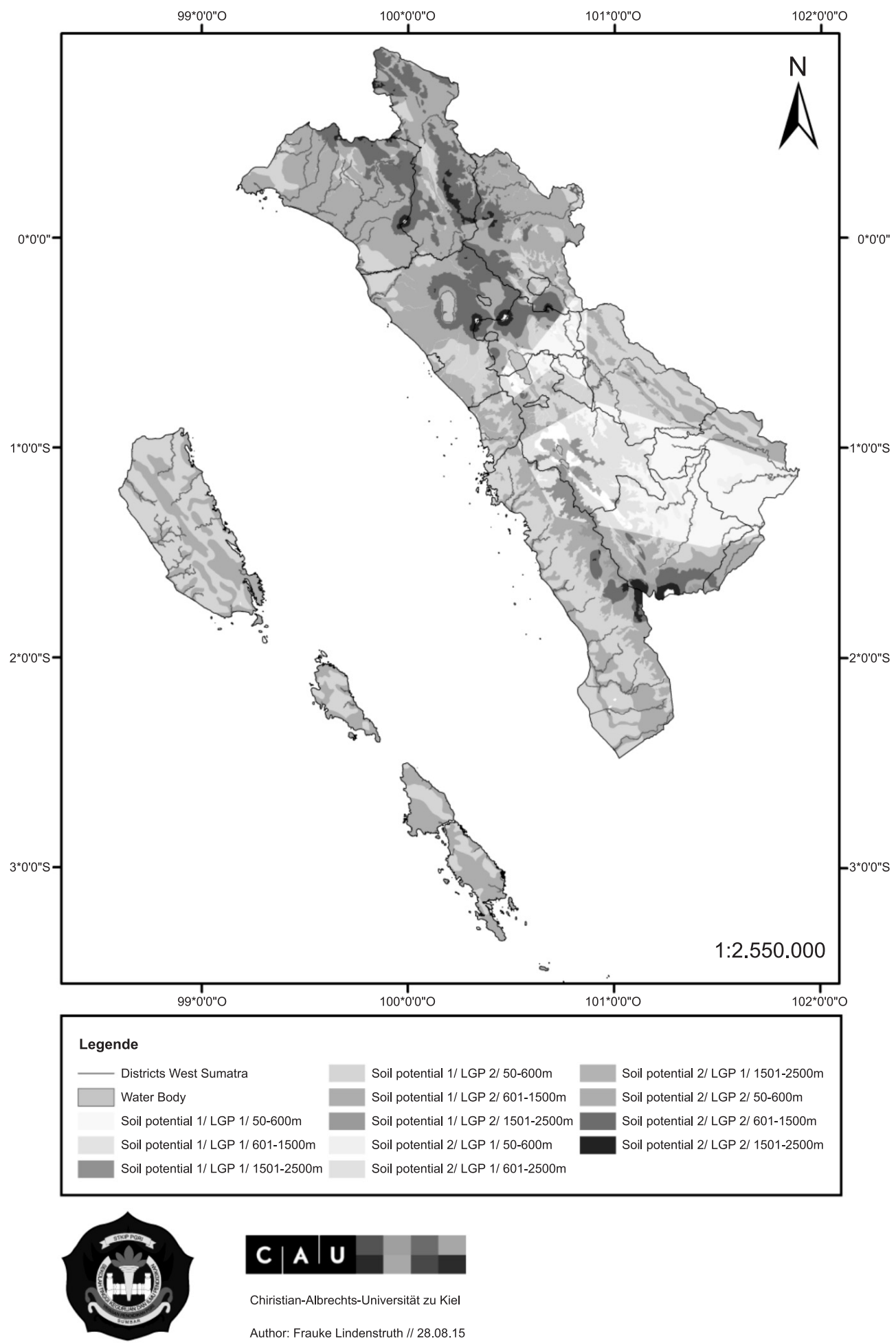

Figure 20.1: Agro-ecological zone of West Sumatra 
Figure 20.1 above shows the agro-ecological zones of West Sumatra using Yunghun approach. There are twelve agro-ecological zones based on soil potential. Soil potential is based on soil fertility such as high and low soil nutrition. The length of growth is determined by climatic factors such as rainfall, humidity and other climatic variables. The result below is the analysis of farmer household revenue for major commodity based on agro-ecological zones in West Sumatra.

The result of analysis model of Ricardian using panel data on farmer's revenue for rubber and oil palm that climate change represented by climate variable (X5) and squared climate variable (log X5) has a sinificant coefficient that affect the revenue of farmers or income per capita in the region that became centers of production of this commodity. The coefficient of quadratict term of climate change has positive value. It means that the impact of climate change on income per capita in the district in form of shaped curve U.

Table 20.1

Regression analysis of Panel data of Farmer revenue for major communities based on AEZ in West Sumatra

\begin{tabular}{lcccc}
\hline \multicolumn{1}{c}{ Variable } & Coefficient & Standard Error & t-Statistic & Probability \\
\hline Constanta & -99.868 & 25.903 & -3.855 & 0.0005 \\
Income percapita & - & 2.137 & 3.898 & 0.0004 \\
Economic growth & 8.335 & $1.40 \mathrm{E}$ & 3.207 & 0.0030 \\
Production Palm Oil & 4.49 & 0.000 & 1.414 & 0.1667 \\
Production rubber & 0.00016 & 0.005 & -2.606 & 0.0136 \\
Price & -0.015 & 0.027 & -2.593 & 0.0141 \\
Square climate change & 14.859 & 5.542 & 2.681 & 0.0114 \\
Fixed Effects (Cross) & & & & \\
_South Coastal District_C & 4.565 & & & \\
_Sijg District_C & 5.678 & & & \\
_West Pasaman District_C & -8.399 & & & \\
_Darmasraya district_C & -2.028 & & & \\
Observation & 11 & - & & \\
$\mathrm{R}^{2}$ & 0.7382 & - & & \\
Adjusted R & & & & \\
Chow Test/Likelihood ratio test & 0.666775 & - & & \\
\hline
\end{tabular}

Changes in economic growth (X1), the oil palm production (X2), the rubber production (X3), price (X4), climate (X5) in the district then gives result on the income per capita of South Coastal District District will be reduced to Rp 9982 units. The Sijunjung district will be reduced to Rp 94.19 unit, West Pasaman district will be reduced by Rp 108.27, and

Dharmasraya district will be reduced by $\mathrm{Rp}$ 101.90. Basen on those results that there are two districts namely Sijunjung and Dharmasraya which have a high degree of sensitivity to climate change.

Figure 20.2 above shows that those four districts are potential area for oil palm and rubber plantation. Dharmasraya district has the biggest impact on their revenue caused by climate change special changing the rainfall. The higher amount of rainfall will impact the marginel revenue in this area. The marginal effect of 
Ansofino, Mabdi, Farida, Afrital Rizki, Frauke Lindenstruth and Yolamalinda

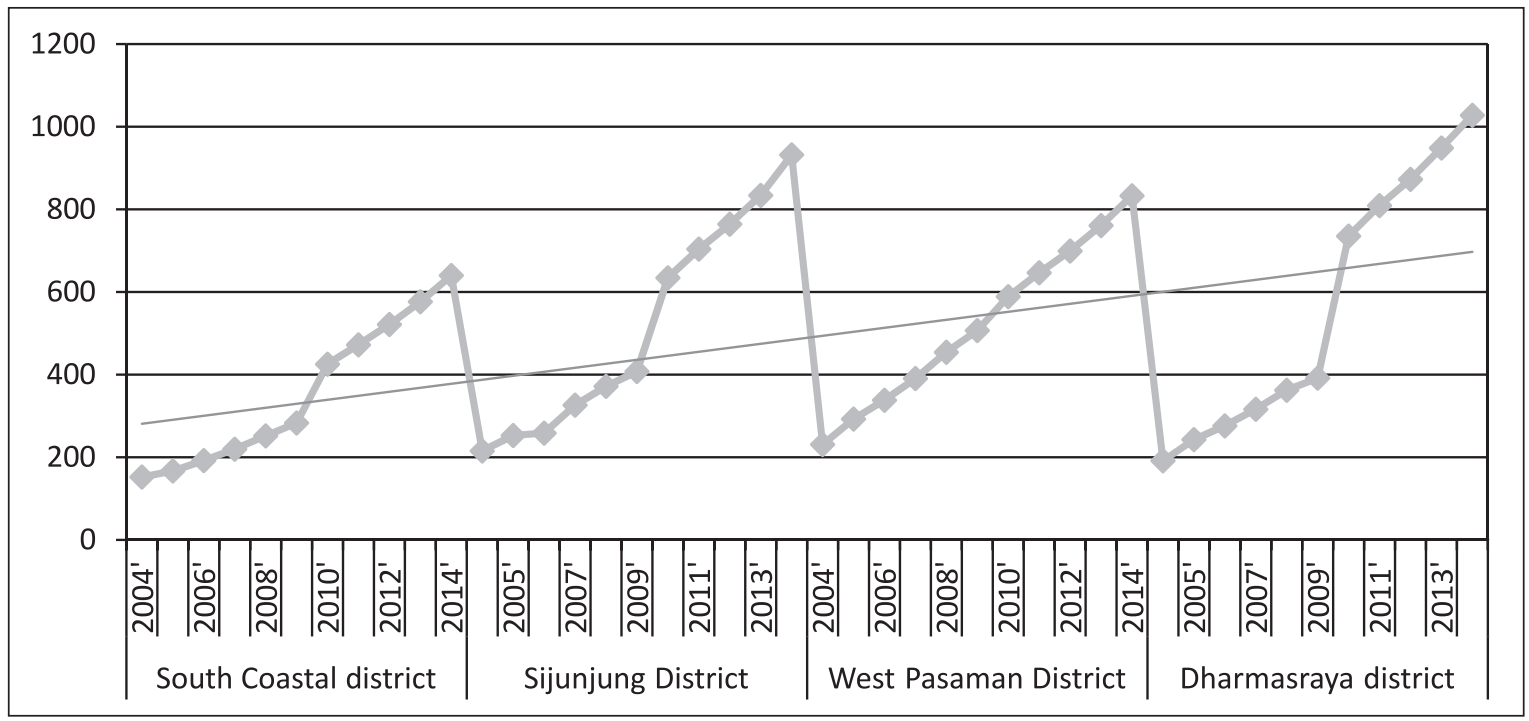

Figure 20.2: Effect of climate change on marginal revenue of oil palm and rubber plantation area in West Sumatra

income per capita as a result of climate change is smaller in South Coastal District district compared with Sijunjung district, West Pasaman and Dharmasraya. The impact of climate change on a per capita income on those four districts occur in different timing of convergence. The most rapid convergent occured in Dharmasraya district on 2009, while Sijunjung and West Pasaman occurred in 2010 and the South Coastal District on 2013.

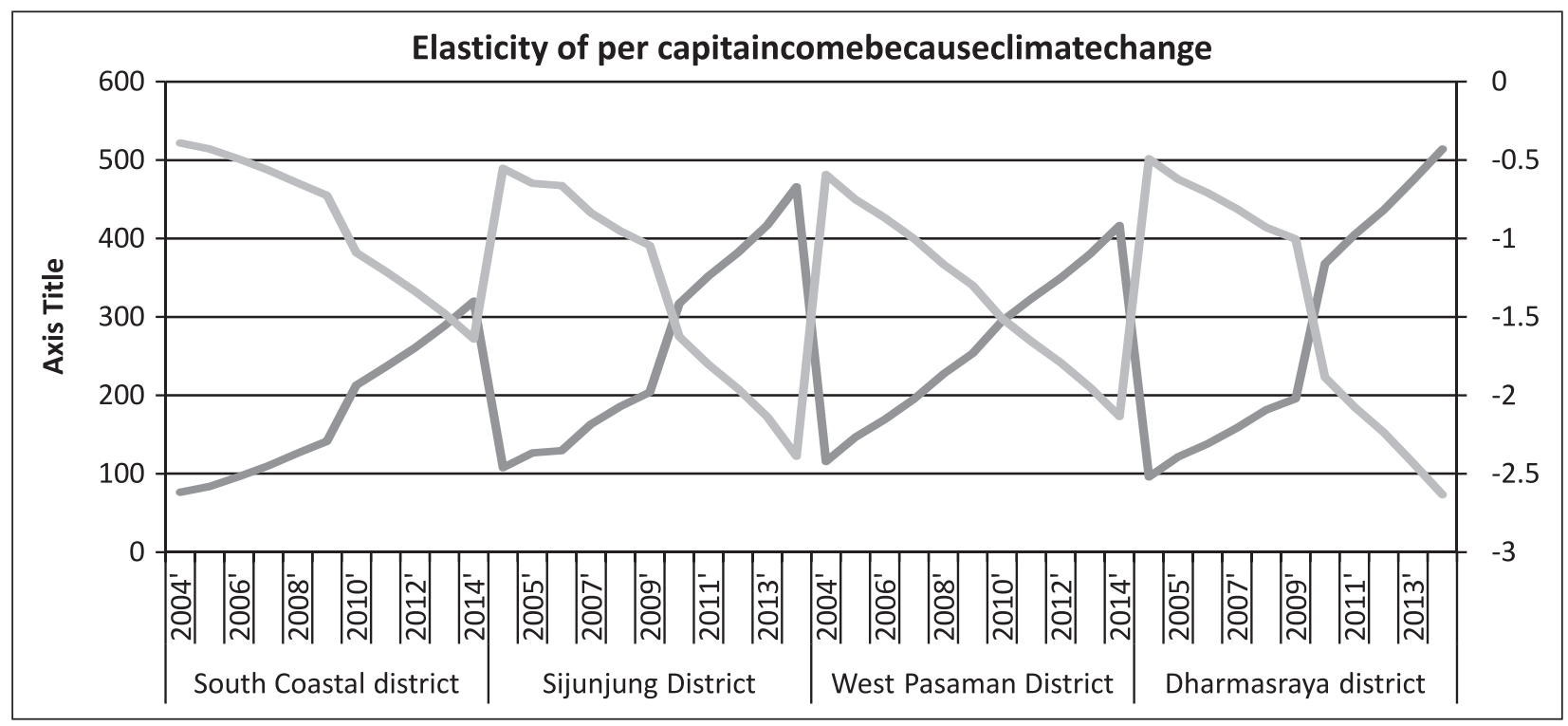

Figure 20.3: Impact of climate change on elasticity of per capita income for major commodities production

Based on elasticity of per capita income due to the climate change that district received fast impact in Dharmasraya district followed by Sijunjung district and West Pasaman in 2010. While South Coastal District district received the impact on revenue per capita there years later in 2013. The difference in time among these four districts caused by forest cover area, soil potential and altitute. 
Empirical data analysis have been performed on Sijunjung district as one of center for rubber plantation as part of efforts to see the impact of climate change on the level of the farmer welfare based on agroecological zones West Sumatra. Data were collected from 42 households of rubber farmers who are in the category of potential zone 1 of AEZ which is a low nutritious area.

The income of farmer households as a measurement of farmer welfare affected significantly with the error rate of $0.05 \%$ and $0.01 \%$ by the amount of rubber production, rubber price, land elevation, and rainfall intensity. The others parametes such as land area, age of farmers, educational level and accessibility to the market do not have real influence on the farmer's income. Based on the result of colinearity analysis test that the rubber price is collinear with production quantities, therefor the prices are excluded from the model. Once the model is free from the multicollinearity, then the regression results show that the amount of production, land area and elevation are very significant variables affecting household income in Sijunjung district on a group soil potential 1.

Heteroscedasticity test using White method gave a value of $\mathrm{R}^{2}$ is 40.66 with a probability of $\mathrm{X}^{2}$ greater than 0.05 . Based on this result it can be said that the model did not have a heteroscedasticity problem. On the autocorrelation test with the value of Durbin Watson statistic is 1.49 with $d u$ as 1.92 and $d l$ as 1.12 shows that the method has not been able to detect the autocorrelation problem. The next test was used Breusch-Godfrey Serial Correlation LM Test. It turned that R-Square Observation value reaches 1.79 and its probability value is greater than the level alpha 0.05 , which means there are autocorrelation problem in the calculations. Thus, the model obtained of farmer's welfare as a result of the effect of changes in production, land use, land elevation, rain intensity, length of formal education and distance to the nearest market is a strong (robust) model. It meets all assumptions of classical regression to be interpreted.

The income of farmer in the soil potential 2 as high nutrious land influenced significantly by land area cultivated by them in all confidence interval. The model obtained meet the assumptions of normality since the statistic value of the Jarque-Bera is 8.00 is smaller than $\mathrm{X}^{2}$ table 0.05 (40). It proves the residual value of regression results are normally distributed and meet the assumptions of normality in the ordinary least square method. The test results of multicollinearity problem of the model shows that all the independent variance inflation factor (VIF) are smaller than 10. Therefor the further analysis can be processed.

The model also meets the assumption homoscedasticity using White test which include the White cross Time, with calculated Chi square as 32.49. It is smaller than the table chi-square which is 55.76 (0.05). It proved that the model did not contain a problem of heteroscedasticity. These models also meet the assumptions which is not have problems of Durbin Watson (DW) statistical autocorrelation. The du value is 2,085 which lies between the values of 1.854 and 2.416. This result show that the area is free from autocorrelation in the DW table.

Therefor the regression model obtained in predicting the effect of climate change on production, land area, price, length of schooling and distance to the nearest market that affected the farmer income in Sijunjung district is a robust model. Then the models can be used to interpret many variables to estimate the changes in household income of Sijunjung rubber farmers. The complete regression results can be seen in the Table 20.2.

Econometrical model that affect the income of Sijunjung rubber farmers in Soil Potential category 1 (SP1) can be written as follows: 


$$
\begin{aligned}
\mathrm{Y}_{\mathrm{SP} 1}= & -562382.5+797.6 \text { Production }+940.3 \text { Age }+466692.5 \text { Land area }+2984.5 \text { elevation } \\
& +454016.8 \text { Rain Intensity }-5446.7 \text { Length of formal school } \\
& +2227.6 \text { Distance to market }-35207.5 \text { Rain intensity square }+\varepsilon_{i} \\
\mathrm{R}^{2}= & \text { 0.4623. } \mathrm{F}_{\text {arithmatic }}=3.55 . \text { Dusbin Watson }=1,87
\end{aligned}
$$

The above model meets all the classical assumptions then this models used to explain the effect of climate change on income of rubber farmers in Sijunjung district. In addition to this model that all the variables simultaneously influenced farmers income based on the F statistic value of 3.55 which is much higher than F table 0.05 (42) of 2.24.

Income of rubber farmers in Soil Potential 1 at Sijunjung district influenced by the amount of production and land area with coefficient 797.6, and 466692.5 respectively. Therefor if there is an increase in production by 1\%, it will increase the income of farmers households as Rp 797.6 million. This is line with the changes in the area of land used for the cultivation of rubber with increasing of rubber plant area of 1 hectare, it will encourage the increased of income of rubber farmers with Rp 46.66 million.

Climate affects the income of rubber farmers through a number of variables, i.e, the land elevation with a coefficient value of 2984.49 which is very significant at $\alpha$ level of 0.01 . While the rain intensity is positively associated with the coefficient value of 455016.8. So if there is $1 \%$ increase in rainfall intensity which is measured by the length of rainy days (hours/day) then it will increase the income of Rp 4.54 million.

While on climate change variable such as squared of climate change affect the income of rubber farmers in Soil Potential 1 at Sijunjung district has a negative coefficient value of 35207 with level of signifinicant $\alpha$ 0.05. It means that if there is a reduced rain intensity, it will encourage the increased of the rubber farmers

\begin{tabular}{|c|c|c|}
\hline \multirow{2}{*}{ Variable } & \multicolumn{2}{|c|}{ Koefisien } \\
\hline & Soil Potensial 1 & Soil Potensial 2 \\
\hline Production_x1 & $797.63^{* *}$ & $1619.64^{* *}$ \\
\hline Land area_x9 & $466692.5^{* *}$ & $0.8955^{* *}$ \\
\hline Price_x2 & - & 0.5114 \\
\hline Elevation_x5 & $2984.49 * *$ & 0.0025 \\
\hline Rain intensity_x4 & $454016.8^{*}$ & -448043.6 \\
\hline Length of formal school_x 7 & -5446.67 & 0.0444 \\
\hline Distance_to market_x6 & 22274.61 & 0.13 .65 \\
\hline Rain intensity square & $-35207^{*}$ & -0.3079 \\
\hline Constant & -562382.5 & 11.1713 \\
\hline Calculated F & 3.5459 & 23.93 \\
\hline $\mathrm{R}^{2}$ & 0.4623 & 0.8040 \\
\hline
\end{tabular}
income as Rp 35.21 (Table 20.2).

Table 20.2

Regression coefficient of farmer welfare on Soil Potensial 1 in Sijunjung district

Note: ** Significant on $1 \%, *$ Significant on $5 \%$

Econometrical model that affect the income of Sijunjung rubber farmers in Soil Potential 2 (SP2) can be written as follows: 


$$
\begin{aligned}
\mathrm{Y}_{\mathrm{SP} 2}= & 511.17+1619.64 \text { Production }+08955 \text { Land area }+0.5114 \text { Pri }+0.003 \text { Elevation } \\
& -448043.6 \text { Rain Intensity }+0.0444 \text { length of formal school } \\
& +0.1365 \text { distance to market }-0.3079 \text { Rain Intensity square }+\varepsilon_{i} \\
\mathrm{R}^{2}= & 0.8040 \mathrm{~F}_{\text {aritmethic }}=23.93, \mathrm{DW}_{\text {statistic }}=2.0852
\end{aligned}
$$

The income of household rubber farmers in Soil Potential 2 at Sijunjung district siginificantly influenced by the production and land area significantly $(1 \%)$. While a number of climate variables such as elevation, rainfall intensity and rainfall intensity squared has not significantly affected the income of the rubber farmers in Soil Potential 2.

Climate variables on Soil Potential 2 such as altitude, rainfall intensity and square of rainfall intensity have not significantly affect the income of the rubber farmers. This is due to the fertility of the land is still able to support the rubber farm. The elevation has less significance to the income of the farmers in Soil Potential 2. It is indicated by the positive coefficients which is not significant on the value of 0.003 . Therefor with the $1 \%$ incrase in elevation then the farmers income will increase by $\mathrm{Rp} 3,000$ units. Rainfall intensity have a greater coefficient in influencing the household income of rubber farmers in Sijunjung district. It has no significant and negative coefficient value as 448043.6, whereby if the rain intensity is reduced, then the income of the rubber farmers will increase by Rp 4.5 million. So it obvious that the climate variables such as rainfall intensity is measured by the number of rainy days, has a big influence on income of rubber farmers.

Variable of climate change squares representing drastic changes in rainfall intensity as part of extreme climate change has a smaller influence on the income of the farmers compared with the negative variable rain intensity of 0.3079 . If there is a drastic change in rain intensity increased by $1 \%$, then the income of household rubber farmers would be reduced by Rp 307, 900 per year. This figure is less than the decline of income of rubber farmers in SP1 which reached Rp 3.5 billion per year.

Comparing the impact of climate change on two areas of agro-ecological zones namely Soil Potential 1 and Soil Potential 2 in the district Sijunjung, we found that rainfall intensity and elevation related to air temperature. Therefor the income of rubber farmer in SP1 more sensitive compare to the ones in SP2.

The implication of these findings that in order to maintain the farmer welfare of farmers in the zone, should pay attention and controlling climate change variable such as dractically change in higher rainfall intensity will reduce the amount of farmer's income in Soil Potential 2. One of the solution to face this situation is to maintain the land cover area to regulate air temperature and cloud formation.

The higher of rainfall intensity in Soil Potential 1 will increase the income of rubber farmer. It related to elevation of Soil Potential area in lowland. However, since it is located in the lowlands, it raises the social cost specially of high rainfall intensity in the lowlands will have potential event of flooding that cause loss of life and community's property. The drastically change of climate variables will reduce the farmer's income in Sijunjung District. The impact of climate change on income of rubber farmer households using Ricardian models can be seen in the Figure 20.4.

The graph above compares the marginal impact of climate change on rubber farmer welfare in the Soil Potential 1 and 2 in Sijunjung district. Based on the graph, we can see the major impact of climate change will affect the farmers in Soil Potential 1 compare to Soil potential 2. The location of rubber farm also influence the decline of farmer's income special the ones who located in low nutrious and lowland. 


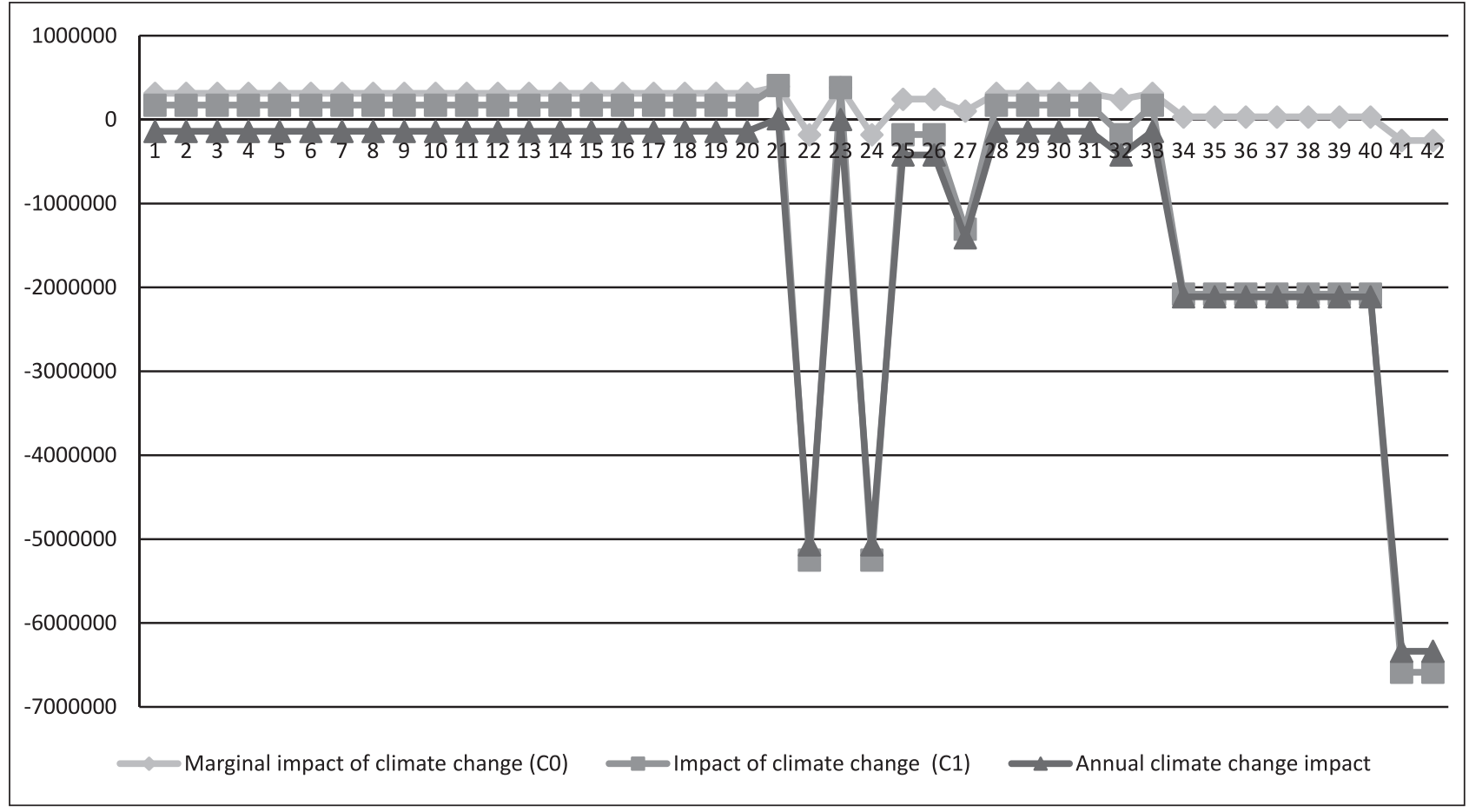

Figure 20.4: Impact of climate change on rubber farmer's income at Soil Potential 1 in Sijunjung District

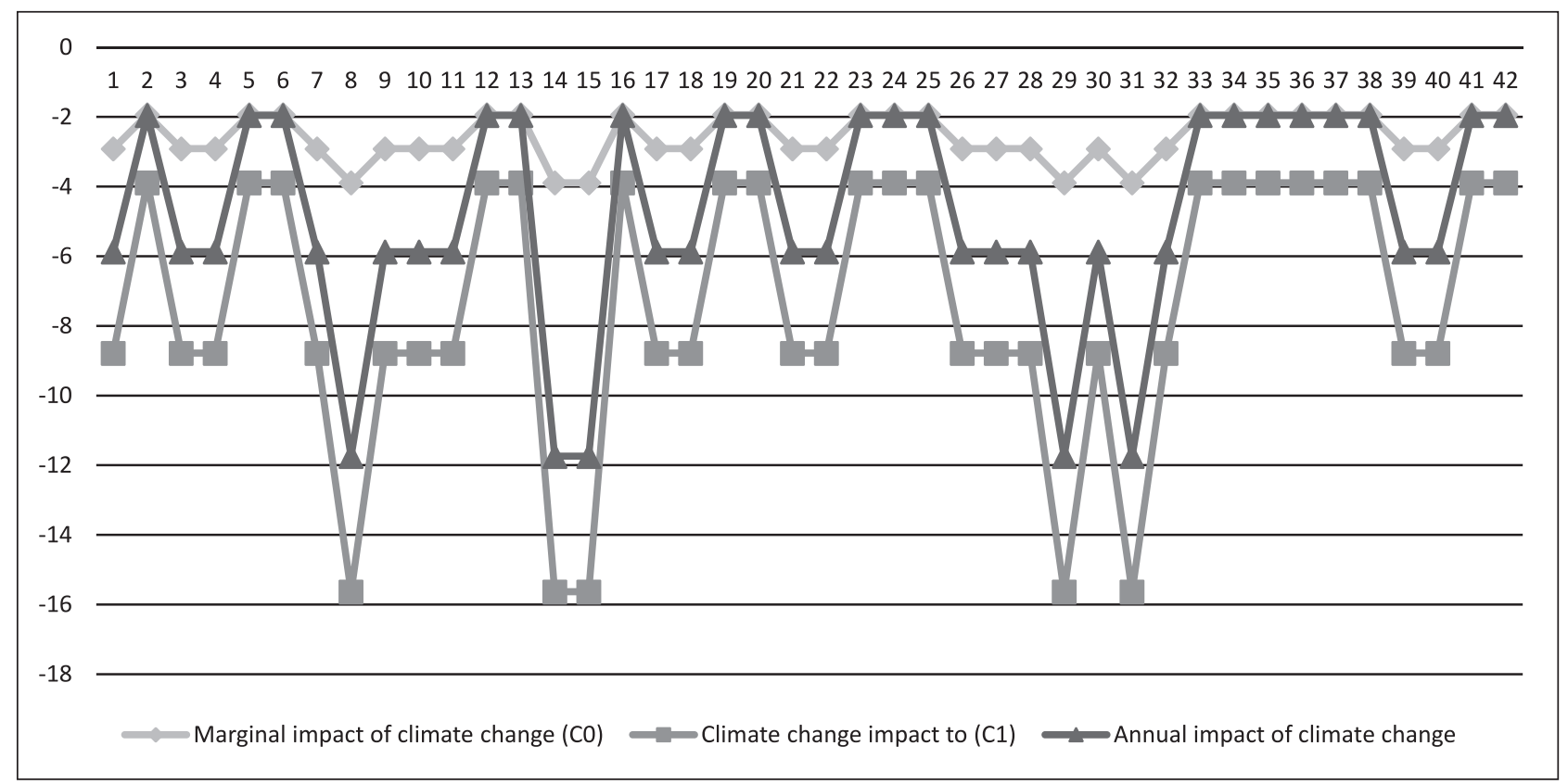

Figure 20.5: Impact of climate change on rubber farmer's income at Soil Potential 2 in Sijunjung District

In both zones, the trend of the declining level of welfare can be seen from a declining trend with repetition samples. So the longer the climate change is likely to lead to a decrease in the level of farmer's income. Therefore, in the long period, both of farmers in Soil potential 1 and 2 will have negative impact due to climate change. The difference in the time and magnitute of climate change impact will be higher in Soil Potential 1 than Soil potential 2. 
Assessing the Climate Change Impact on Farmers Household Welfare According to West Sumatra Agro-Ecological Zone

\section{CONCLUSIONS AND IMPLICATIONS}

1. There are twelve AEZ of West Sumatra based on soil potensial classification and elevation. These two variables had been used for describe the AEZ of West Sumatra.

2. Climate change has significant and positive impact on household revenue with coefficient of 14.85. This value will increase for farmers located in West Pasaman and Dharmasraya with higher fixed effect.

3. The biggest impact of climate change on household revenue in Dharmasraya and Sijunjung district caused by low soil nutrition (soil potential 1) while in West Pasaman and South Coastal District dominantly on soil potensial 2 with good soil nutrition.

4. Higher elasticity of per capita income in the area of AEZ with soil potential 1 compared to soil potensial 2. Therefor climate change has a big impact on farmer's welfare on soil potensial 1 zone than soil potential 2. The implication of farmer's revenue will decrease as impact of climate change in soil potential 1. Soil potential 1 need additional input for soil fertility.

5. The biggest impact of climate change is on farmer households in the zone AEZ SP1 is more likely to suffer a decline compared to the annual welfare household rubber farmers in the zone AEZ SP2. The more effort rubber plants are located on less fertile land in the lowlands, more vulnerable to climate change impacts to declines income annually.

6. The negative impact of climate change on Soil Potential 1 regard to their welfare declined every year compare to Soil Potential 2. The low land and low fertility rubber farm will increase the vurnerability of farmer's income due to climate change.

7. The impact of climate change is likely to lead to a decrease in the level of income of household rubber farmers. The impact of climate change is faster and more pronounced in Soil Potential 1 compared Soil Potential 2.

\section{Reference}

Ansofino. (2009), Penentuan Kawasan dan Pengembangan Komoditi unggulan Sub Sektor Peternakan dan Perikanan untuk Meningkatkan Perekonomian Sumatera Barat. Menara Ilmu, UMSB, Vol. II No. (Juli 2009).

Ansofino. (2010), Penentuan Kawasan dan Pengembangan Komoditi Unggulan Sub sektor Perkebunan untuk Meningkatkan Perekonomian Sumatera Barat. Menara Imu, Vol. II No. (September), 1-18.

Ansofino. (2011), Penentuan Kawasan dan Pengembangan Komoditi unggulan Sub Sektor Tanaman Pangan dan Hortikultura untuk Meningkatkan Perekonomian Sumatera Barat. Jurnal Pelangi, STKIP PGRI Sumatera Barat, Vol. 4, No. (September), 1-24.

Ansofino, Mahdi, Ai Farida, Rezki, A. (2016), Mitigation and adaptation of climate change impact on farmers household welfare according to west sumatra agroecology zone. Proceeding International 1 (ICEEE1st) 2016, 1, (8).

Bierbaum, R.M., \& Zoellick, R.B. (2009), Development and climate change. Science (New York, N.Y.) (Vol. 326). http://doi. org/10.1126/science.1183876.

Choumert, J., Motel, P.C., \& Millock, K. (2015), Climate change mitigation and adaptation in developing and transition countries: introduction to the special issue. Environment and Development Economics, 20(4), 425-433. http://doi. org/10.1017/S1355770X15000145. 
Fischer, Gunther, Velthuizen, Harrij, Shah, Mahendra, Nachtergaele, F. (2002), Global Agro-ecological Assessment for Agriculture in the 21st Century: Methodology and Results. FAO, UN (Vol. RR-02-02). http://doi.org/http://www.iiasa.ac.at/Admin/ PUB/Documents/RR-02-002.pdf.

Kurukulasuriya, P., \& Mendelsohn, R. (2008), A Ricardian Analysis of the Impact of Climate Change on African Cropland. AfJARE, 2(1), 23.

Mendelsohn, R., Dinar, A., \& Williams, L. (2006), The distributional impact of climate change on rich and poor countries. Environment and Development Economics, 11(2), 159. http://doi.org/10.1017/S1355770X05002755.

Millner, A., \& Dietz, S. (2014), Adaptation to climate change and economic growth in developing countries. Political Science, 1(69), 1-33. http://doi.org/10.2139/ssrn.1935349.

Niggol Seo, S., \& Mendelsohn, R. (2008), A Ricardian Analysis of the Impact of Climate Change on South American Farms. Chilean Journal of Agricultural Research, 68(1), 69-79. http://doi.org/10.4067/S0718-58392008000100007.

Ramírez, J.B., Kronick, D., \& Mason, A. (2012), Rural households in a changing climate, (January). Retrieved from http:// www.econstor.eu/handle/10419/67273.

Seo, S.N., Mendelsohn, R., Dinar, A, Hassan, R., \& Kurukulasuriya, P. (2008), A Ricardian Analysis of the Distribution of Climate Change Impacts on Agriculture across Agro-Ecological Zones in Africa. Policy Research Working Paper 4599, (April). 